\title{
Combination and distribution of reservoir space in complex carbonate rocks
}

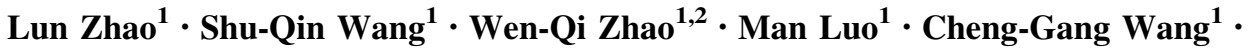 \\ Hai-Li Cao ${ }^{1} \cdot \operatorname{Ling~} \mathrm{He}^{1}$
}

Received: 6 August 2015/Published online: 8 August 2016

(c) The Author(s) 2016. This article is published with open access at Springerlink.com

\begin{abstract}
This paper discusses the reservoir space in carbonate rocks in terms of types, combination features, distribution regularity, and controlling factors, based on core observations and tests of the North Truva Oilfield, Caspian Basin. According to the reservoir space combinations, carbonate reservoirs can be divided into four types, i.e., pore, fracture-pore, pore-cavity-fracture, and pore-cavity. Formation and distribution of these reservoirs is strongly controlled by deposition, diagenesis, and tectonism. In evaporated platform and restricted platform facies, the reservoirs are predominately affected by meteoric fresh water leaching in the supergene-para-syngenetic period and by uplifting and erosion in the late stage, making both platform facies contain all the above-mentioned four types of reservoirs, with various pores, such as dissolved cavities and dissolved fractures, or structural fractures occasionally in favorable structural locations. In open platform facies, the reservoirs deposited continuously in deeper water, in an environment of alternative high-energy shoals (where pore-fracture-type reservoirs are dominant) and low-energy shoals (where pore reservoirs are dominant).
\end{abstract}

Keywords Caspian Basin - Carbonate rock of platform facies - Reservoir space type - Reservoir type - Controlling factor $\cdot$ Distribution regularity

Shu-Qin Wang

wshuqin@petrochina.com.cn

1 Research Institute of Petroleum Exploration and Development, CNPC, Beijing 100083, China

2 School of Energy Resources, China University of Geosciences, Beijing 100083, China

Edited by Jie Hao

\section{Introduction}

Carbonate reservoirs contribute about $60 \%$ of the world's oil and gas production. The Caspian Basin is one of the major petroliferous basins in the world, where over $90 \%$ of the oil and gas production is from carbonate reservoirs. Compared with sandstone reservoirs, carbonate reservoirs often have stronger heterogeneity due to more complex genesis (Jiang et al. 2014a, b). Many researchers have recognized that the carbonate reservoirs in the Caspian Basin are very complex in diagenesis and fracture formation (Wang et al. 2012a, b; Zhao et al. 2010, 2012; Xu 2011). The authors think the heterogeneity of the carbonate reservoirs is the combined result of complex distribution and combination of reservoir space, i.e., pore, cavity, and fracture. Thus, finding out distribution features of such reservoir space is essential for evaluating the heterogeneity of carbonate reservoirs. Taking the North Truva Oilfield in the eastern margin of the Caspian Basin as an example, based on core observations and tests, this paper discusses the features and genesis of pores, fractures, and dissolved cavities in carbonate reservoirs of open platform-evaporated platform facies. It gives a classification of the carbonate reservoirs according to the features of their reservoir space, describes their physical property features, and analyzes the distribution and combination regularity and controlling factors of different types of carbonate reservoirs.

\section{Overview}

The North Truva Oilfield is located in the eastern margin of the Caspian Basin (Fig. 1). Its main oil-bearing formations are Carboniferous carbonate reservoirs of platform facies, 


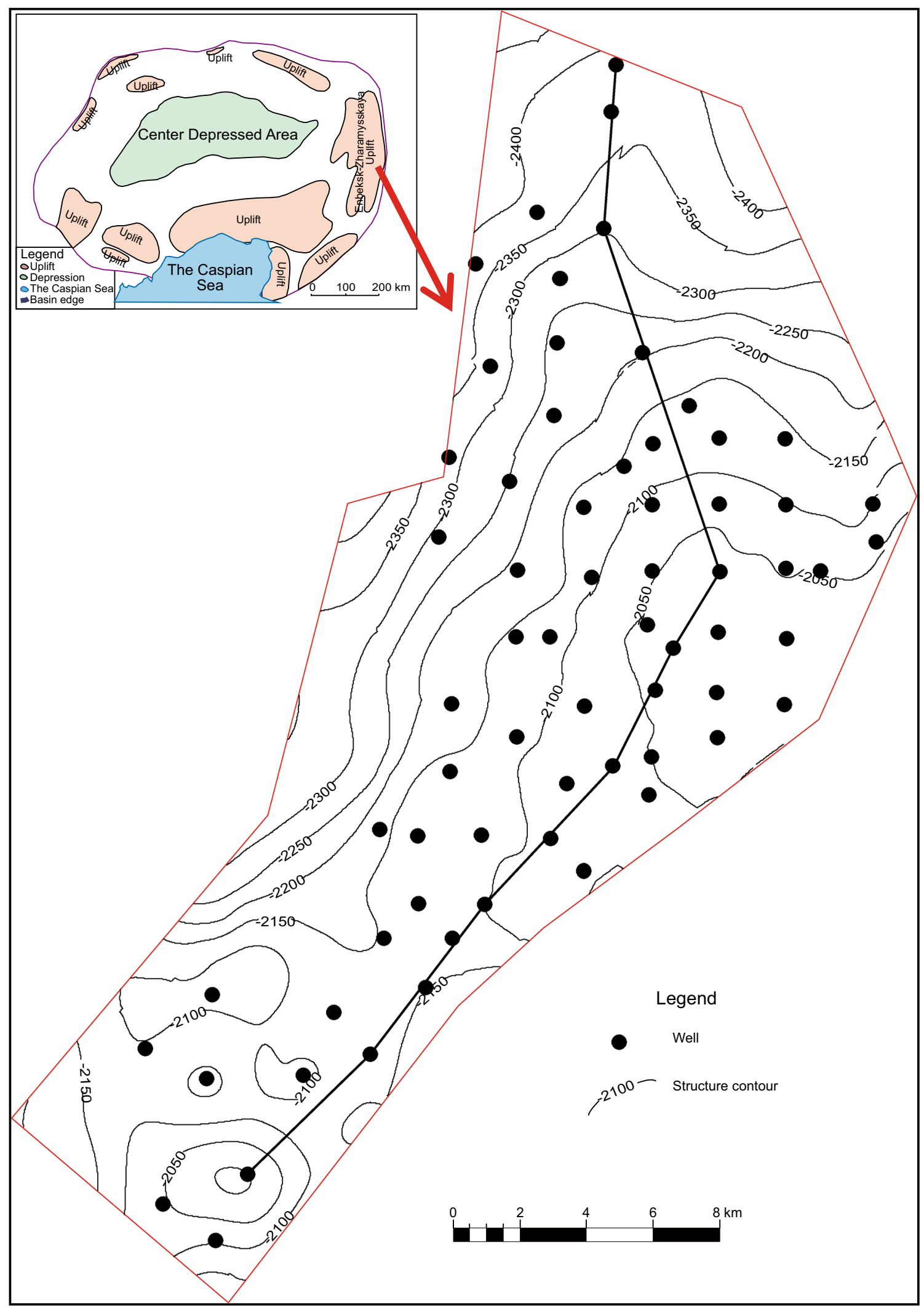

Fig. 1 Location and structural map of the study area 
including KT-I and KT-II; two sets of oil/gas-bearing zones vertically. KT-I, composed of deposits of evaporated platform-restricted platform facies at the burial depth of 2300-2800 m, is further divided into A, 5 , and B oil layers. Layer A presents evaporated platform facies in the north part, and transits to restricted platform facies southwards, from top to bottom, with water depth during deposition gradually increasing. It is composed of calcareous dolomite, dolomitic limestone and anhydrite-bearing dolomite, anhydrite dolomite, with dolomitic and gypsum content decreasing but calcareous content increasing from the evaporated platform to restricted platform facies (Fig. 2a) (Esrafili-Dizaji and Rahimpour-Bonab 2009). A1 and part of A2 are missing in the north of the oilfield, indicating that the area experienced uplifting and erosion after the deposition of Carboniferous and before deposition of Permian. Core analysis of KT-I shows that its porosity is $7.2 \%-$ $39.2 \%$, with an average of $16.9 \%$, and permeability is $0.025-2170 \mathrm{mD}$, with an average of $107.3 \mathrm{mD}$. KT-II represents the carbonate rocks of open platform facies at a burial depth of 3100-3400 m, with depositional water depth decreasing and energy enhancing from bottom to top, since it is dominated by low-energy shoal deposits in the lower part and high-energy shoal deposits in the upper part. KT-II is mostly composed of pure bioclastic limestone, with calcareous content of $99.6 \%$ (Fig. 2b). Core analysis shows that its porosity is $8 \%-20.1 \%$, with an average of $12.1 \%$, and permeability is $0.003-415 \mathrm{mD}$, with an average of $35.9 \mathrm{mD}$.

\section{Types and genesis of reservoir space}

9600 core samples taken from 23 wells were analyzed to ascertain the features and genesis of the major reservoir space of KT-I and K-II, and the reservoir space is classified according to their genesis and shape. The main types of reservoir space in the study area are pores, fractures, and dissolved cavities. For KT-I and KT-II, pores account for $84 \%$ and $97.8 \%$, dissolved cavities account for $6.7 \%$ and $0 \%$, and fractures account for $9.3 \%$ and $2.2 \%$, respectively.

\subsection{Pores}

Pores are defined as reservoir space less than $2 \mathrm{~mm}$ in diameter, which are the most widespread type of reservoir space in the study area, and also the most complicated. By genesis, pores in the study area can be divided into 7 subcategories under 2 categories (Table 1), i.e., primary pores (syngenetic or para-syngenetic) and mainly secondary pores formed during burial diagenesis (Zheng et al. 2010). Primary pores are the pores formed in syngenetic or para-syngenetic periods during deposition, with shapes and sizes changing during diagenesis. In the study area, the most prominent primary pores are intergranular pores preserved after the compaction between detrital grains, visceral foramen preserved after soft body decomposition, and the pores preserved between biological frameworks (Fig. 3a, b, c). Secondary pores refer to the pores formed by dissolution during the process of burial diagenesis, which are dominated by intergranular dissolved pores, intragranular dissolved pores, and intercrystalline dissolved pores (Fig. 3d, e, f). The distribution of pore types is significantly influenced by the depositional-diagenetic environment (Yue et al. 2005; Gao et al. 2013; Haq and AlQahtani 2005).

KT-I is composed of deposits of evaporated platformrestricted platform facies. Its deposits were affected by sabkha dolomitization and reflux-seepage dolomitization during syngenetic, para-syngenetic, and eogenetic periods and further transformed due to dissolution and cementation during burial diagenesis. In Late Carboniferous, the entire study area was uplifted and eroded by meteoric leaching (Huang et al. 2009; López-Horgue et al. 2010; Wang et al. 2012a, b). Due to the effect of multiple factors, the reservoirs have various pores, including primary (including syngenetic and para-syngenetic) pores, interframework pores and visceral foramen, and secondary pores, such as intergranular dissolved pores, intragranular dissolved pores, intercrystalline dissolved pores, crystal moldic pores, etc. Meanwhile, the average surface porosity is almost the same for all pores. Primary visceral foramen, intergranular dissolved pores, intragranular dissolved pores, and intercrystalline dissolved pores are $2.15 \%$ $3.45 \%$ in average surface porosity (Fig. 4), not differing much.

KT-II is dominated by deposits of open platform facies, including bioclastic shoals, algal reef, and intershoal deposits developed in deeper water, which are continuous and free from uplifting and erosion in later stages. The formation of reservoir pores was controlled by dissolution and cementation during diagenesis, predominately including various primary (syngenetic or para-syngenetic) visceral foramen remaining after soft tissue decomposition and intergranular dissolved pores, and intragranular dissolved pores formed due to selective dissolution of soluble components during burial diagenesis. The average surface porosity of visceral foramen, intergranular dissolved pores, and intragranular dissolved pores are $1.8 \%, 5.24 \%$, and $0.46 \%$ respectively, and less than $0.1 \%$ for other types of pores (Fig. 4).

\subsection{Fracture}

Fracture, another kind of reservoir space commonly found in the study area, is also an important oil and gas flow 

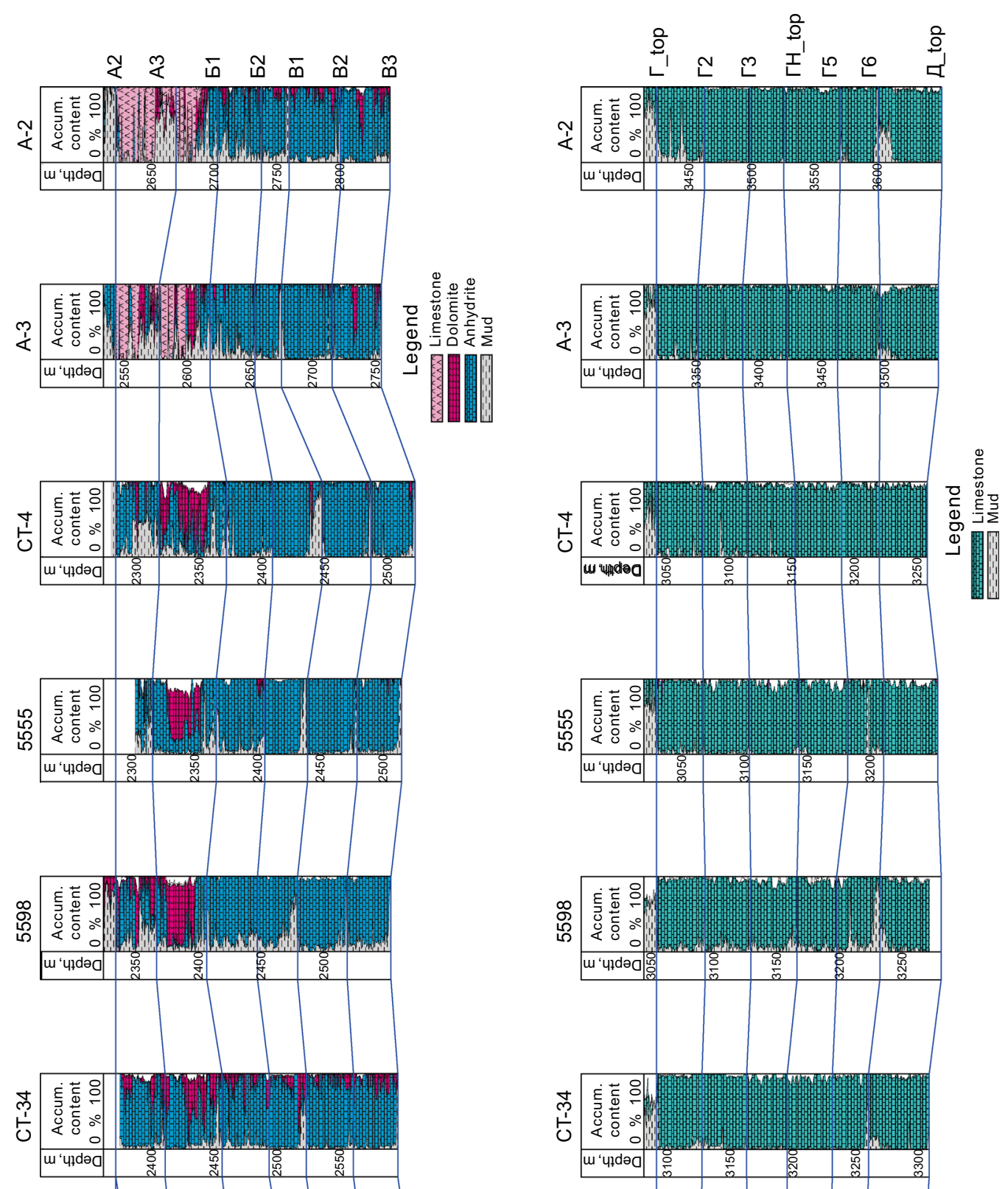

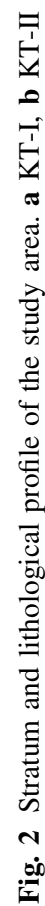


Table 1 Classification and definition of pore types in the study area

\begin{tabular}{|c|c|c|}
\hline \multicolumn{2}{|l|}{ Classification } & \multirow[t]{2}{*}{ Definition } \\
\hline Category & Subcategory & \\
\hline \multirow[t]{3}{*}{ Primary pores } & Intergranular pores & $\begin{array}{l}\text { The space not filled by marl or cement between grains or the partially filled residual } \\
\text { pores }\end{array}$ \\
\hline & Interframework pores & $\begin{array}{l}\text { The framework space formed due to reef-building, the unfilled or partially filled } \\
\text { pores }\end{array}$ \\
\hline & Visceral foramen & $\begin{array}{l}\text { The visceral foramen remaining after the decomposition of soft tissues, unfilled or } \\
\text { partially filled residual pores }\end{array}$ \\
\hline \multirow[t]{4}{*}{ Secondary pores } & Intergranular dissolved pores & $\begin{array}{l}\text { The pores formed by partial or complete dissolution of the micrite or sparry } \\
\text { cements previous filled between particles }\end{array}$ \\
\hline & Intragranular dissolved pores & $\begin{array}{l}\text { Pores inside bioclastic, oolitic, and sand clast grains formed due to partial } \\
\text { dissolution }\end{array}$ \\
\hline & Intercrystalline dissolved pores & Enlarged dissolved pores between powder crystalline and fine crystalline \\
\hline & Crystal moldic pores & Formed by complete dissolution of gypsum or salt crystals \\
\hline
\end{tabular}

channel. Various types of fractures are observed in cores from the study area. These can be divided into structural fractures and nonstructural fractures according to their genesis (Davies and Smith Jr. 2006; Wang et al. 2012a, b; Zheng et al. 2009). Structural fractures, formed due to fracturing of rocks under stress fields (Figs. 3h, 5b-d), arrange in a certain direction. Nonstructural fracture including dissolved fracture and pressure dissolved fracture (sutures), has no apparent directionality (Figs. 3i, 5e, f). The fractures can also be divided into macrofractures and microfractures according to their extended length. The former refer those in cores visible to the naked eye, while the latter can be only identified under a microscope.

During the depositional period of KT-II, the open platform water energy changed intermittently, leading to the alternate deposition of high-energy shoals, low-energy shoals, and inter shoals (the low-lying land between shoals). Nonreservoirs deposited between shoals are tight and strong in resistance to pressure, while reservoirs between shoals are loose and weak in resistance to pressure. Under tectonic stress, the reservoirs of high-energy shoals and low-energy shoals would release pressure first since their particles were breaking up, resulting in the formation of microfractures; then, the tight nonreservoirs between shoals would form macrofractures. Thus, structural macrofractures of open platform facies carbonate deposition are mostly present in tight nonreservoirs, accounting for $84.4 \%$, and seldom in low-energy shoals. High-energy shoals are dominated by granular fracturing microfractures.

The reservoirs deposited in the evaporated platformrestricted platform facies are mostly calcareous dolomite and dolomitic limestone with strong brittleness, while nonreservoirs are composed of argillaceous and gypsum rocks with strong plasticity. Thus, under tectonic stress, the reservoir interval is more likely to form structural fractures due to fracturing (Aqrawi et al. 1998; Carnell and Wilson 2004; He et al. 2012; Moutaz et al. 2010). Fractures account for $71 \%$ of the reservoir space in the reservoir interval but $29 \%$ of the space in the nonreservoir interval. During the syngenetic-para-syngenetic period, dissolved fractures were likely to form due to strong leaching by meteoric fresh water. The uplifting and erosion after Carboniferous deposition and before Permian deposition leached the formations with meteoric water again, making the dissolved fractures and structural fractures formed earlier enlarge further. Therefore, dissolved fractures are quite abundant in these reservoirs. But they are small in scale, mostly dissolved microfractures, and bigger ones are only found in local areas (Fig. 5f).

The statistical results of microfractures observed from thin sections of reservoir intervals show that there are more structural microfractures and dissolved fractures in KT-I than KT-II, with a surface fracture ratio of $0.04 \%$ and $0.28 \%$, respectively, that is $2-10$ times that of KT-II, but the granular fracturing microfractures of KT-II have a higher surface fracture ratio than that of KT-I (Fig. 4). KTII is tighter and more brittle than KT-I, so macrofractures are richer in KT-II. The statistical results of cores and imaging logging reveal that the linear fracture density is $6.49 / \mathrm{m}$ for KT-II and 3.38/m for KT-I.

\subsection{Dissolved cavities}

Dissolved cavities refer to reservoir space more than $2 \mathrm{~mm}$ in diameter. They are only found in the evaporated platform facies of KT-I, but are absent in KT-II. The formation of dissolved cavities in KT-I is mainly due to dissolution of carbonate components, which is directly related to meteoric leaching by weathering and erosion resulted from the 

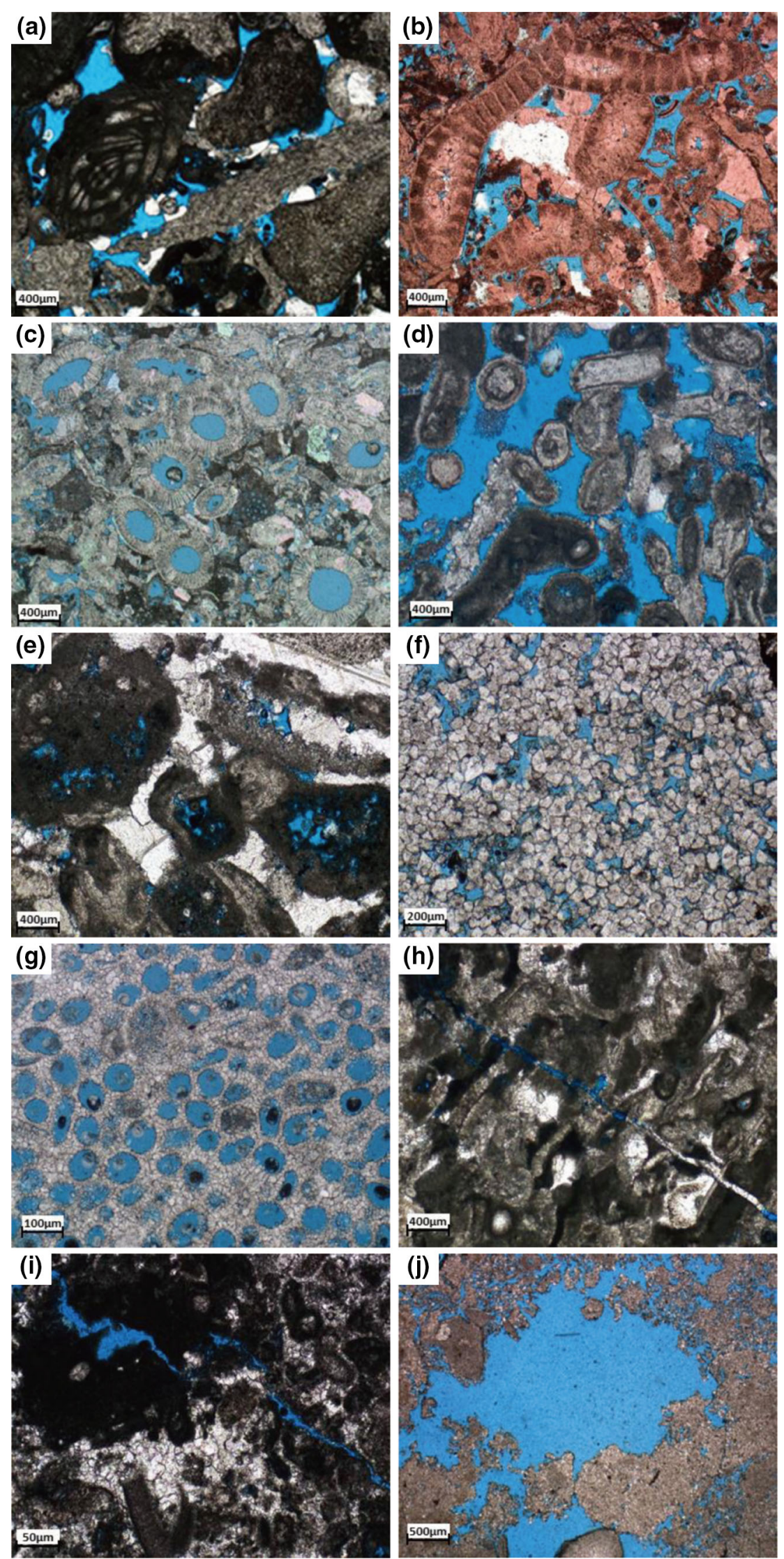
४Fig. 3 Microscopic features of reservoir space. a Residual intergranular pores after cementation and compaction, Well CT-22, $3170.28 \mathrm{~m}$, sparry algal limestone; b green algae framework pores, Well 5555, $3123.16 \mathrm{~m}$, micrite green framework limestone; $\mathbf{c}$ visceral foramen within derbesia neglecta, Well 5598, $3155.13 \mathrm{~m}$, micrite foraminiferal red algae limestone; $\mathbf{d}$ superficial oolith intergranular dissolved pores, Well 5598, $3201.37 \mathrm{~m}$, sparry algae superficial oolitic limestone; e dissolved pores within algae aggregate, Well CT22, $2339.72 \mathrm{~m}$, micrite foraminiferal red algal limestone; $\mathbf{f}$ dolomitic intercrystalline dissolved pores, Well CT-4, $2335.52 \mathrm{~m}$, coarse powdery crystalline dolomite; $\mathbf{g}$ oolite moldic pores, pore diameter: 0.05-0.1 mm, Well A2, $2887.27 \mathrm{~m}$, sparry moldic oolitic limestone; h structural fracture, half-filled by calcite, Well CT-22, 3148.82-3148.85 m, sparry algae foraminiferal limestone; i dissolved fracture, Well CT-22, $2301.15 \mathrm{~m}$, micrite foraminiferal limestone; j large dissolved cavity, pore diameter: $2-5 \mathrm{~mm}$, Well CT-4, $2342.48 \mathrm{~m}$, powdery crystalline residual bioclastic dolomite

late-stage uplifting (Guo 2011; Müller et al. 1990; Yao et al. 2008). Core observations and image logging data show there are apparent dissolved cavities at the top of KTI, which are 3-5 $\mathrm{mm}$ in diameter generally, and up to $25 \mathrm{~m}$ at maximum (Fig. 5g-h). Dissolved cavities, pores, and fractures generally coexist. Microanalysis of core thin sections shows the dissolved cavity porosity in KT-1 is $0.45 \%$.

\section{Features of reservoir space combination}

The analysis above reveals that the reservoir space in evaporated platform-restricted platform facies is dominated by pores, fractures, and dissolved cavities, while the reservoir space in open platform facies has pores and fractures, without dissolved cavities. Different types of reservoir space are not evenly distributed in different layers and positions, which manifests in differences in reservoir space combinations. Based on core observations, and combination of pores, fractures, and dissolved cavities, the reservoirs in the study area can be divided into four types, i.e., pore, fracture-pore, pore-fracture-cavity, and porecavity (Borkhataria et al. 2005; Huang 1997; Mahdi and Aqrawi 2014; Whitaker et al. 2004). The porosity and permeability of these different types of reservoirs were determined from logging data to compare their physical properties.

\subsection{Pore-type reservoir}

This type of reservoir contains reservoir space of pores of different genesis, with an average porosity of $9.8 \%$ and average permeability of $5.7 \mathrm{mD}$ (Table 2). Pore-type reservoirs are most widespread in all intervals, but differ widely in physical properties in different intervals. KT-I has various types of pores, and higher porosity and permeability than KT-II. The porosity and permeability are $10.9 \%$ and $6.1 \mathrm{mD}$ for KT-I, and $9.7 \%$ and $5.2 \mathrm{mD}$ for KT-II. Moreover, their porosity and permeability show a gradually decreasing trend from top to bottom. For KT-I, this variation in physical properties was controlled by meteoric fresh water leaching and uplifting erosion, but for KT-II, the variation in physical properties is controlled by the sedimentary environment, the $\Gamma 1-\Gamma 5$ layers are highenergy shoal facies with an average porosity of $9.9 \%$ $10.7 \%$, and average permeability of $4.7-14.8 \mathrm{mD}$; while the Г6-Д3 layers are low-energy shoal facies with an average porosity of $8.5 \%-9.9 \%$ and average permeability of $0.6-2.2 \mathrm{mD}$. It is obvious that the reservoirs of upper high-energy shoal facies have better physical properties than those of low-energy shoal facies.

\subsection{Fracture-pore-type reservoir}

This type of reservoir mainly contains pores and fractures of varying genesis. Second in extensiveness, it has an

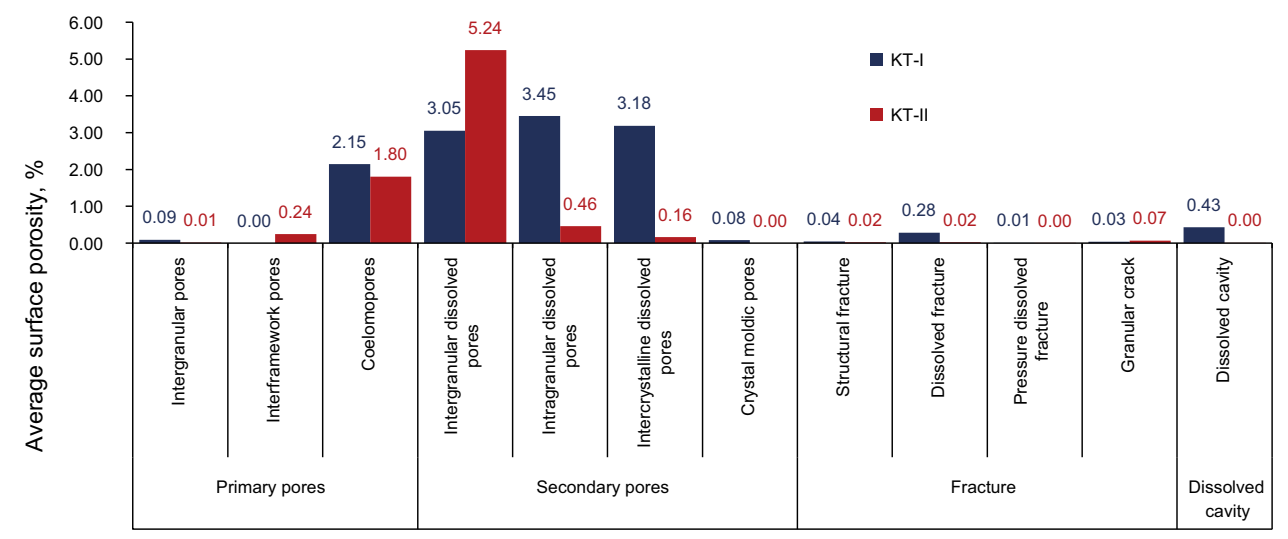

Fig. 4 Surface porosity of reservoir space (microscope) obtained from the statistics of core thin sections 

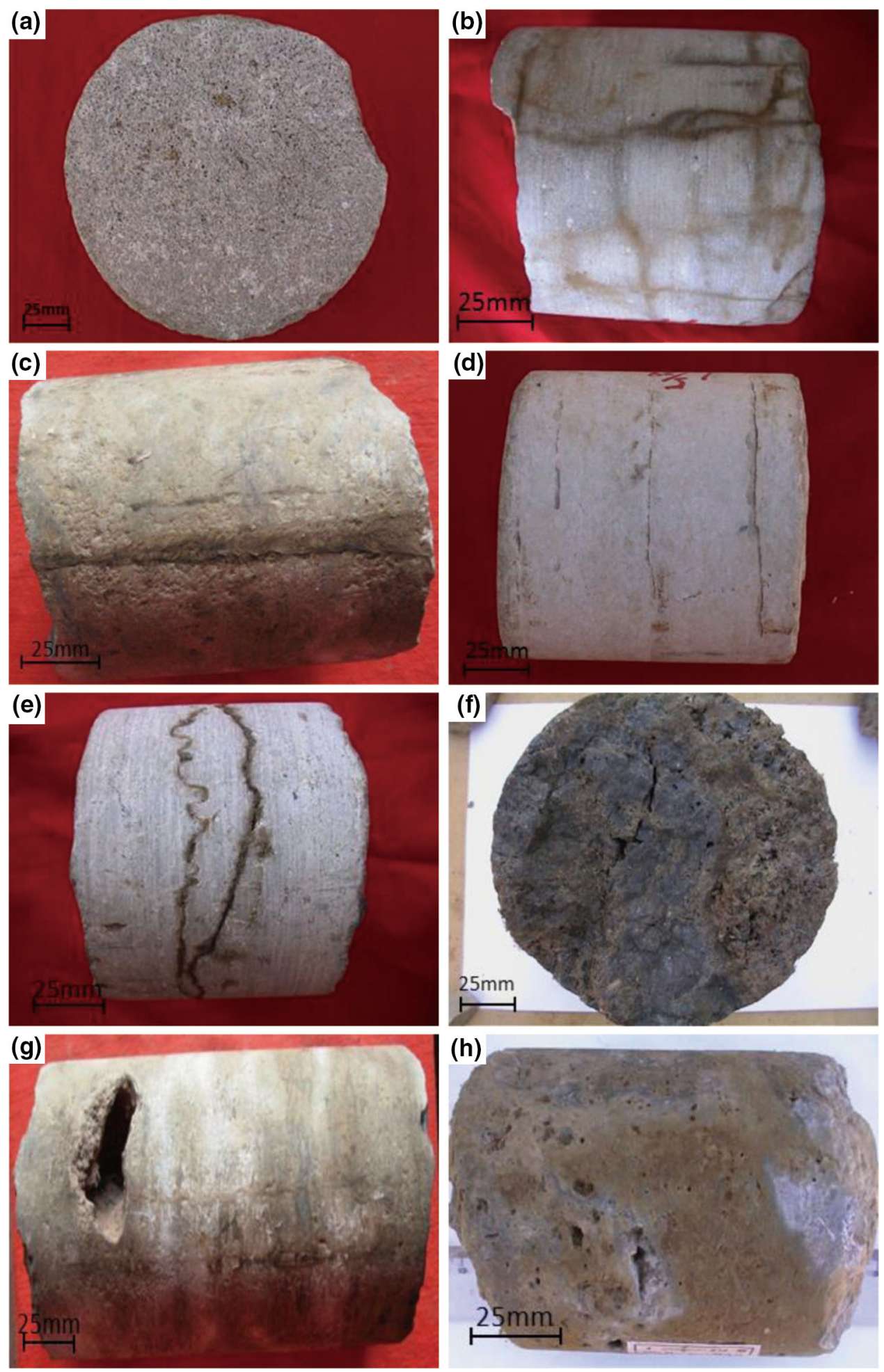

Fig. 5 Macroscopic features of reservoir space. a Poorly connected pores, Well A2, 3466.21-3466.24 m, limestone; b netted fracture, Well CT10, 2343.06-2343.17, dolomitic limestone; c high-angle structural fracture, Well 5555, 2332.15-2333.49 m, dolomitic limestone; d low-angle structural fracture, Well CT-4, 2294.90-2395.02 m, dolomitic limestone; e suture line, Well CT10, 2350.46-2350.58 m, dolomitic limestone; f dissolved fracture, Well CT4, 2346.72-2346.96 m, dolomitic limestone; g dissolved cavity, Well 5555, 2341.03-2341.26 m, dolomite with oil patch and dissolved cavity; h dissolved cavity, Well CT4, 2341.54-2341.66 m, dolomitic limestone 
Table 2 Physical properties of various types of reservoirs

\begin{tabular}{|c|c|c|c|c|c|c|c|c|c|c|}
\hline \multirow[t]{2}{*}{ Horizon } & \multicolumn{5}{|c|}{ Porosity, \% } & \multicolumn{5}{|c|}{ Permeability, mD } \\
\hline & $\begin{array}{l}\text { Pore- } \\
\text { cavity }\end{array}$ & Pore & $\begin{array}{l}\text { Pore-cavity- } \\
\text { fracture }\end{array}$ & $\begin{array}{l}\text { Fracture- } \\
\text { pore }\end{array}$ & Average & $\begin{array}{l}\text { Pore- } \\
\text { cavity }\end{array}$ & Pore & $\begin{array}{l}\text { Pore-cavity- } \\
\text { fracture }\end{array}$ & $\begin{array}{l}\text { Fracture- } \\
\text { pore }\end{array}$ & Average \\
\hline A1 & & 11.6 & 12.1 & 10.1 & 11.4 & & 5.1 & 3.0 & 1.8 & 4.3 \\
\hline A2 & 14.3 & 10.8 & 14.4 & 11.5 & 12.1 & 49.0 & 15.1 & 54.5 & 8.2 & 25.4 \\
\hline A3 & 13.1 & 10.2 & 13.0 & 10.6 & 11.7 & 18.3 & 5.3 & 17.9 & 7.0 & 12.2 \\
\hline Б1 & 14.2 & 11.0 & & 10.2 & 11.5 & 43.2 & 2.9 & & 4.6 & 11.0 \\
\hline Б2 & & 10.0 & & 9.0 & 9.7 & & 3.1 & & 4.2 & 3.3 \\
\hline B1 & & 10.0 & & 8.9 & 9.7 & & 1.0 & & 2.9 & 1.6 \\
\hline B2 & & 9.8 & & 10.0 & 9.9 & & 3.3 & & 9.6 & 5.5 \\
\hline B3 & & 13.2 & & 10.8 & 13.0 & & 2.1 & & 3.4 & 2.2 \\
\hline B4 & & 12.4 & & 12.9 & 12.5 & & 0.4 & & 2.7 & 0.8 \\
\hline B5 & & 10.1 & & & 10.1 & & 1.3 & & & 1.3 \\
\hline KT-I & 13.9 & 10.9 & 13.2 & 10.7 & 11.7 & 40.1 & 6.1 & 22.8 & 6.9 & 13.4 \\
\hline$\Gamma 1$ & & 9.9 & & 8.6 & 9.0 & & 4.7 & & 4.3 & 4.4 \\
\hline$\Gamma 2$ & & 10.4 & & 10.8 & 10.5 & & 7.6 & & 13.2 & 9.9 \\
\hline Г3 & & 10.4 & & 10.1 & 10.3 & & 8.3 & & 6.3 & 7.3 \\
\hline$\Gamma 4$ & & 10.7 & & 11.2 & 10.9 & & 8.4 & & 15.6 & 12.4 \\
\hline$\Gamma 5$ & & 10.2 & & 10.3 & 10.3 & & 14.8 & & 25.4 & 19.2 \\
\hline$\Gamma 6$ & & 9.0 & & 9.1 & 9.0 & & 2.2 & & 8.1 & 3.5 \\
\hline Д1 & & 8.5 & & 8.1 & 8.5 & & 0.6 & & 1.5 & 0.6 \\
\hline Д2 & & 9.4 & & 8.4 & 9.3 & & 1.6 & & 1.8 & 1.6 \\
\hline Д3 & & 9.7 & & 8.2 & 9.7 & & 0.8 & & 1.0 & 0.8 \\
\hline KT-II & & 9.7 & & 10.4 & 9.9 & & 5.2 & & 12.3 & 7.8 \\
\hline Oilfield & 13.9 & 10.1 & 13.2 & 10.5 & 10.8 & 40.1 & 5.2 & 22.8 & 9.8 & 10.5 \\
\hline
\end{tabular}

average porosity of $10.5 \%$ and average permeability of $9.8 \mathrm{mD}$. This type of reservoir in KT-I and KT-II are similar in porosity, but as KT-II is tighter and more brittle, structural macrofractures and microfractures are more likely to form under tectonic stress in KT-II, which can significantly improve reservoir permeability, therefore, this type of reservoir in KT-II has higher permeability than that in KT-I (12.3 mD for the former and 6.9 for the latter) (Table 2).

\subsection{Pore-fracture-cavity-type reservoir}

With pores, fractures, and cavities of various genesis as reservoir space, this type of reservoir mainly occurs in Layer A at the top of KT-I, and is composed of calcareous dolomite with minor dolomitic limestone. Reservoir space in this type of reservoir is most diverse due to the combined effects of meteoric leaching and uplifting and erosion, including pores, fractures, and dissolved cavities of various origins. The fractures are dominated by diagenetic dissolved fractures, followed by structural fractures. This type of reservoir largely occurs in A1, A2, and A3 layers in the upper part of KT-I 30-80 m below the KT-I top. With an average porosity of $13.2 \%$ and average permeability of $22.8 \mathrm{mD}$ (Table 2), it is one type of reservoir with fairly good physical properties in the study area. The A2 layer in the central north of the oilfield, high in structural position, and suffering strong deformation, is best in physical properties, with an average porosity of $14.4 \%$ and an average permeability of $54.5 \mathrm{mD}$.

\subsection{Pore-cavity-type reservoir}

Often associated with pore-fracture-cavity reservoirs, this type of reservoir has pores and cavities of various origins as reservoir space, and occurs in A2, A3, and B1 layers. It is composed of dolomitic limestone, the dissolved cavities are mostly unfilled or partially filled, and connected by pores of various sizes. With an average porosity of $13.1 \%$ $14.3 \%$ and an average permeability of $40.1 \mathrm{mD}$, it is the reservoir type with the best physical properties in the study area (Table 2). 


\section{Distribution regularity of reservoir types}

The thicknesses of various types of reservoirs in KT-I of 156 wells and KT-II of 146 wells were compiled and the thickness ratio of various types of reservoirs was analyzed by sublayer to find out the thickness variation pattern of different types of reservoirs in the vertical direction and horizontally.

The different types of carbonate reservoirs follow different variation patterns in the vertical direction (Fig. 6) strongly controlled by deposition and diagenesis. KT-I has all four types of reservoir, due to its complicated sedimentary-diagenetic environment, thus it has diverse reservoir space and reservoir space combinations. Of which, layer A with all four types of reservoirs is most diverse in reservoir type. Layer $\bar{b}$ has three types of reservoirs, pore, fracture-pore, and pore-cavity type (Fig. 6). Layer B has only two types of reservoirs, pore, and fracture-pore types. Pore-fracture-cavity reservoirs mainly occur in sublayers A1, A2, and A3 at the top of KT-I, its thickness ratio in three sublayers are $13.9 \%$, $22.1 \%$, and $49 \%$, respectively. Pore-cavity-type reservoirs mainly occur in A2-52 sublayers, at a thickness ratio of $1.6 \%-19.5 \%$. Found in all sublayers, pore-type reservoirs increase in thickness ratio from top to bottom, and reach $100 \%$ in the B5 sublayer. Fracture-pore-type reservoirs occur in all sublayers except B5, with a thickness ratio of $9.8 \%-28.7 \%$. In general, the thicknesses of pore-cavity-fracture, pore, and fracture-pore-type reservoirs account for $32.6 \%, 28.7 \%$, and $27.0 \%$, respectively, while pore-cavity type reservoirs account for $4.7 \%$ in thickness. The above changes in reservoir type have a direct effect on the reservoir physical properties, as a result, the permeability of reservoirs in A1-51 is much higher than the permeability of reservoirs in the 52-B5 sublayer (Table 2).

Deposited in a simple depositional-diagenetic environment, thus monotonous in lithology, KT-II only has two types of reservoir space, pore and fracture, and only two reservoir types, pore and fracture-pore. These two types of reservoirs show patterns in thickness variation, the thickness ratio of fracture-pore reservoirs drops down from the upper sublayer $\Gamma 1$ which is $70 \%$ to the underneath sublayer Д3 which is $1.5 \%$; while the thickness ratio of poretype reservoirs increases up from the upper sublayer $\Gamma 1$ which is $30 \%$ to the underneath sublayer Д3 which is $98.5 \%$. The change in reservoir type directly affects the reservoir physical properties. As a result, the permeability of reservoirs in $\Gamma 1-\Gamma 5$ in the upper part is much higher than those in Г6-Д3 (Table 2).

Horizontally, pore-type and fracture-pore-type reservoirs are widespread, but thinner in relatively higher part of structures in K-I (Fig. 7a, b). Pore-cavity-fracture-type reservoirs and pore-cavity-type reservoirs are predominately distributed in structural high positions because tectonic stress is stronger there, fractures are more developed, and dissolution is more likely to occur when fluid flows into the reservoirs via the fractures formed in the early stage. Furthermore, the structural high positions often have been uplifted by large amounts, so leaching and erosion are more intense in the late stage. Under this tectonic and diagenetic environment, a large quantity of dissolved fractures, dissolved pores, and dissolved cavities are formed in structural high positions, resulting in concentrated distribution of pore-cavity-fracture-type reservoirs and pore-cavity-type reservoirs there.

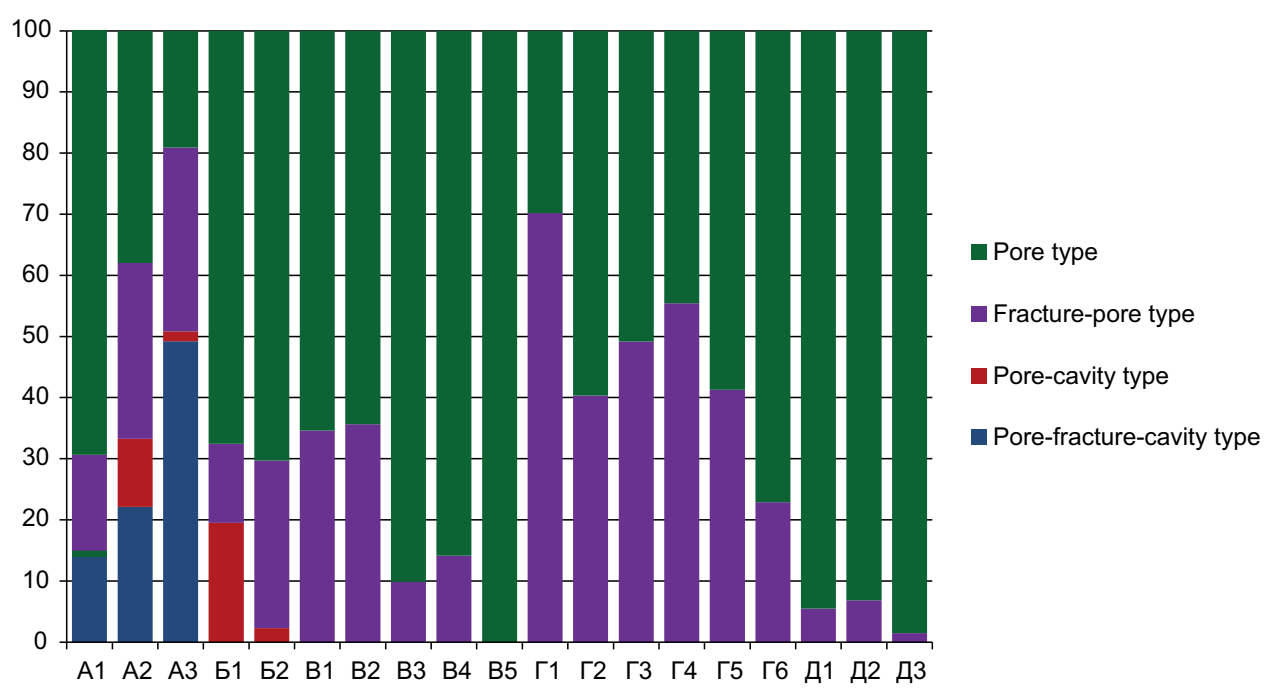

Fig. 6 Thickness ratio of various types of reservoirs in the study area 

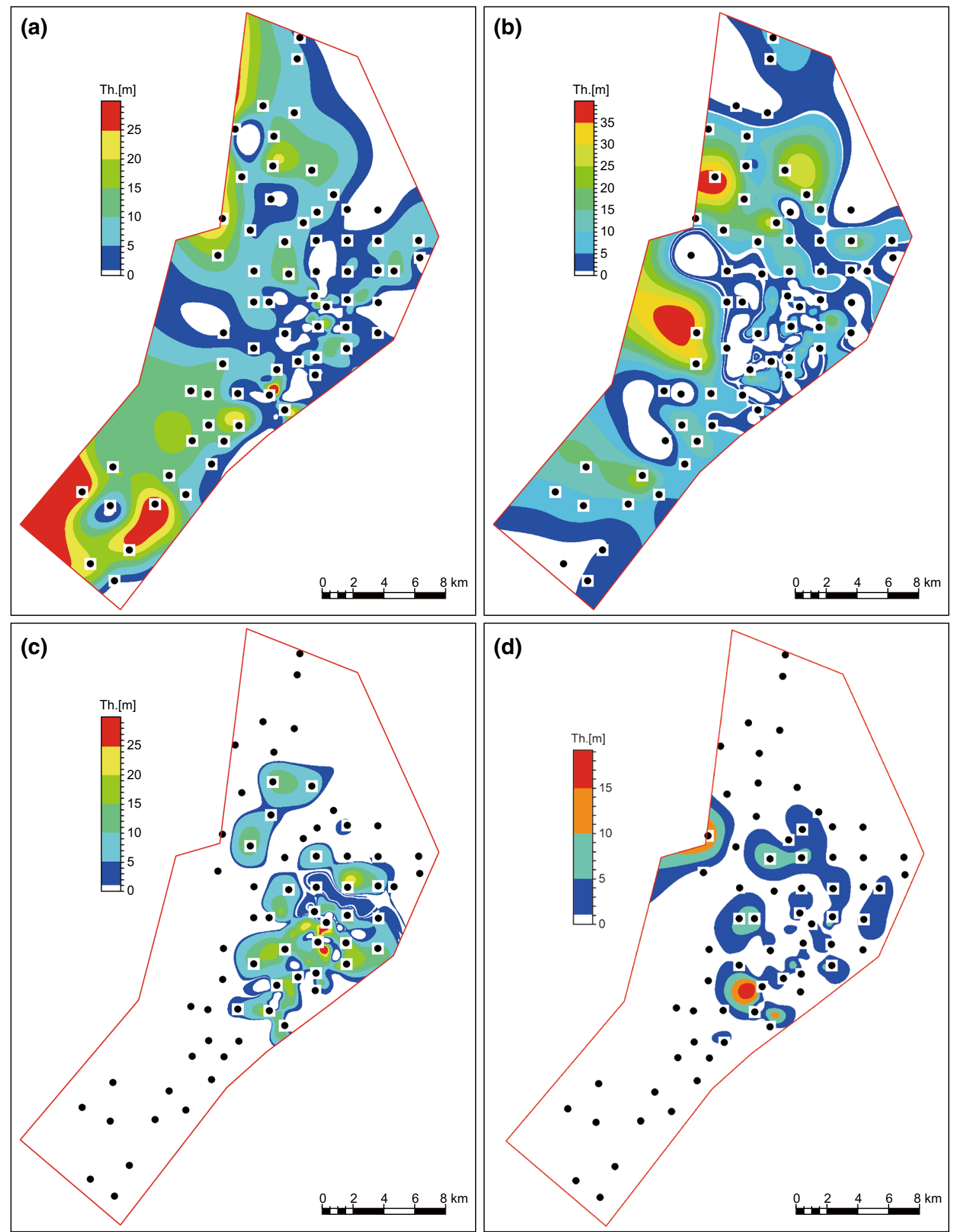

Fig. 7 Reservoir-type distribution in KT-I. a Pore type, b fracture-pore type, c pore-fracture-cavity type, $\mathbf{d}$ pore-cavity type

Horizontally, pore-type and fracture-pore-type reservoirs are widespread in KT-II (Fig. 8), fracture-pore-type reservoirs are mainly distributed in structural high positions on an NE trend. This is because structural stress is stronger at structural highs, and under the effect of structural stress, fractures are likely to be created in the reservoir. In contrast, pore-type reservoirs mainly controlled by deposition and diagenesis, have no apparent regularity in distribution. 

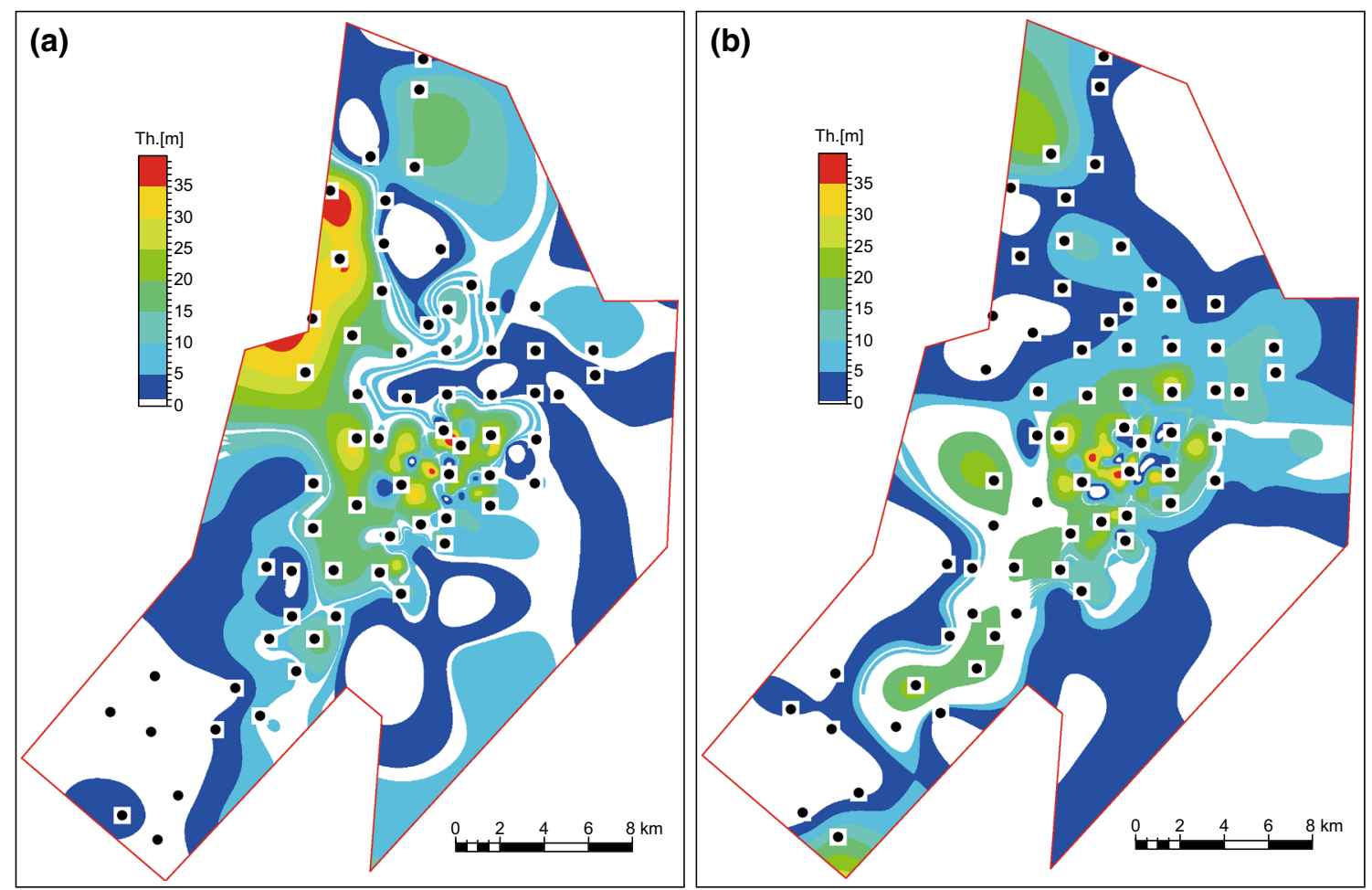

Fig. 8 Reservoir-type distribution in KT-II. a Pore type, b fracture-pore type

\section{Conclusions}

Observation of a large quantity of core samples and core analysis data of the North Truva Oilfield in the eastern margin of the Caspian Basin reveals that in the carbonate reservoirs there are many kinds of reservoir space, including pores, fractures, and dissolved cavities of different genesis, and complex reservoir space combinations. Accordingly, the reservoirs can be divided into four types, i.e., pore, fracture-pore, pore-cavity-fracture, and porecavity types. The distribution of these reservoirs is controlled by deposition, diagenesis, and tectonism. In evaporated platform and restricted platform facies, affected by meteoric fresh water leaching in supergene-para-syngenetic periods and uplifting and erosion in later stages, there developed pores of various types, including dissolved cavities and fractures, and structural fractures at favorable structural positions. So the reservoirs are versatile in type, including all the above four types. In open platform deeper water facies, the deposition was continuous, the depositional environment of alternative high-energy shoals and low-energy shoals directly controlled the degree of fracture development, so pore-type reservoirs dominate in low-energy shoals, while pore-fracture reservoirs dominate in high-energy shoals.

Acknowledgments This paper is supported by the National Major Science and Technology Project (No. 2016ZX05030002).
Open Access This article is distributed under the terms of the Creative Commons Attribution 4.0 International License (http://creative commons.org/licenses/by/4.0/), which permits unrestricted use, distribution, and reproduction in any medium, provided you give appropriate credit to the original author(s) and the source, provide a link to the Creative Commons license, and indicate if changes were made.

\section{References}

Aqrawi AAM, Thehni GA, Sherwani GH, et al. Mid-Cretaceous rudist-bearing carbonates of the Mishrif Formation: an important reservoir sequence in the Mesopotamian Basin. J Pet Geol. 1998;21(1):57-82.

Borkhataria R, Aigner T, Poppelreiter M, et al. Characterisation of epeiric "layer-cake" carbonate reservoirs: upper Muschelkalk (Middle Triassic), the Netherlands. J Pet Geol. 2005;28(2):119-46.

Carnell AJH, Wilson MEJ. Dolomites in SE Asia—varied origins and implications for hydrocarbon exploration. Geol Soc Lond. 2004;235:255-300.

Davies GR, Smith LB Jr. Structurally controlled hydrothermal dolomite reservoir facies: an overview. AAPG Bull. 2006;90(11):1641-90.

Esrafili-Dizaji B, Rahimpour-Bonab H. Effects of depositional and diagenetic characteristics on carbonate reservoir quality: a case study from the South Pars gas field in the Persian Gulf. Pet Geosci. 2009;15(4):325-44.

Gao JX, Tian CB, Zhang WM, et al. Characteristics and genesis of carbonate reservoir of the Mishrif Formation and Rumaila oil field, Iraq. Acta Pet Sin. 2013;34(5):843-52.

Guo F. Carbonate sedimentology. Beijing: Petroleum Industry Press; 2011. 
Haq BU, Al-Qahtani AM. Phanerozoic cycles of sea-level change on the Arabian platform. Geoarabia. 2005;10(2):127-60.

He YL, Fu XY, Liu B, et al. Control of oolitic beaches sedimentation and diagenesis on reservoirs in Feixianguan Formation, northeastern Sichuan Basin. Pet Explor Dev. 2012;39(4):434-43 (in Chinese).

Huang SJ. Carbon and strontium isotopes of Late Palaeozoic marine carbonates in the Upper Yangtze platform, Southwest China. Acta Geol Sin. 1997;71(3):45-53 (in Chinese).

Huang SJ, Tong HP, Liu LH, et al. Petrography, geochemistry and dolomitization mechanisms of Feixianguan dolomites in Triassic, NE Sichuan, China. Acta Pet Sin. 2009;25(10):1363-72 (in Chinese).

Jiang L, Worden RH, Cai CF, et al. Dolomitization of gas reservoirs: The Upper Permian Changxing and Lower Triassic Feixianguan Formations, Northeast Sichuan Basin, China. J Sediment Res. 2014a;84(10):792-815.

Jiang L, Worden RH, Cai CF, et al. Thermochemical sulfate reduction and fluid flow evolution of the Lower Triassic Feixianguan Formation sour gas reservoirs; the Northeast Sichuan Basin, China. AAPG Bull. 2014b;98(5):947-73.

López-Horgue MA, Iriarte E, Schröder S, et al. Structurally controlled hydrothermal dolomites in Albian carbonates of the Asón valley, Basque Cantabrian Basin, Northern Spain. Mar Pet Geol. 2010;27(5):1069-92.

Mahdi TA, Aqrawi AAM. Sequence stratigraphic analysis of the midCretaceous Mishrif Formation, Southern Mesopotamian Basin, Iraq. J Pet Geol. 2014;37(3):287-312.

Moutaz AD, Jassim AJ, Saad AJ. Depositional environments and porosity distribution in regressive limestone reservoirs of the Mishrif Formation, Southern Iraq. Arab J Geosci. 2010;3(1):67-78.

Müller DW, McKenzie JA, Mueller PA. Abu Dhabi sabkha, Persian Gulf, revisited: application of strontium isotopes to test an early dolomitization model. Geology. 1990;18(7):618-21.
Wang J, Liu HQ, Xu J, et al. Formation mechanism and distribution law of remaining oil in fracture-cavity reservoirs. Pet Explor Dev. 2012a;39(5):585-90 (in Chinese).

Wang SQ, Zhao L, Cheng XB, et al. Geochemical characteristics and genetic model of dolomite reservoirs in the eastern margin of the Pre-Caspian Basin. Pet Sci. 2012b;9:161-9.

Whitaker FF, Smart PL, Jones GD. Dolomitization: from conceptual to numerical models. Geol Soc. 2004;235:99-139.

$\mathrm{Xu} \mathrm{KQ}$. Characteristics of hydrocarbon migration and accumulation and exploration practice in the Eastern Margin of the PreCaspian Basin. Beijing: Petroleum Industry Press; 2011. p. 37-50.

Yao GS, Shen AJ, Pan WQ, et al. Carbonate reservoirs. Beijing: Petroleum Industry Press; 2008.

Yue DL, Wu SH, Lin CY, et al. Remaining oil distribution controlled by intercalation in reef limestone reservoir. Pet Explor Dev. 2005;32(4):113-8.

Zhao L, Li JX, Li KC, et al. Fracture development and formation mechanism for complex carbonate reservoirs-a case study on Kazakhstan Zahnanor oilfield. Pet Explor Dev. 2010;3:304-9 (in Chinese).

Zhao WZ, Shen AJ, Hu SY, et al. Geological conditions and distributional features of large-scale carbonate reservoirs onshore China. Pet Explor Dev. 2012;39(1):1-12 (in Chinese).

Zheng RC, Dang LR, Zheng C, et al. Diagenetic system of carbonate reservoirs in Huanglong Formation from the east Sichuan to north Chongqing area. Acta Pet Sin. 2010;31(2):237-45 (in Chinese).

Zheng RC, Wen HG, Zheng C, et al. Genesis of dolostone of the Feixianguan Formation, Lower Triassic in the NE Sichuan Basin: evidences from rock structure and strontium content and isotopic composition. Acta Pet Sin. 2009;25(10):2459-68 (in Chinese). 